\title{
Effect of Soil Amendments on Growth and Yield of Wheat (Triticum aestivum L.) in Sodic Soil
}

\author{
Manish Rao*, K.K. Verma, Gurmukh Gyani, Anoop Singh and Ashok Kumar
}

Department of Soil Science \& Agriculture Chemistry, Department of Agronomy, Narendra Deva University of Agriculture and Technology, Kumar Ganj Faizabad - 224229 (U.P.), India

*Corresponding author

\section{A B S T R A C T}

\section{Keywords \\ Wheat, Gypsum, Organic materials, Reclamation, Sodic soils \\ Article Info \\ Accepted: \\ 06 August 2018 \\ Available Online: \\ 10 September 2018}

Salt-affected soils occur in several countries of the world, especially in the arid and semiarid areas and also in coastal tracts. In India, more than 7.0 million hectares of land is affected by salinity and alkalinity (Anonymous, 2015). In Uttar Pradesh area of saltaffected soil is 1.295 million hectares (Anonymous, 2015). Such soils cannot be economically utilized for crop production because they adversely affect the growth and yield of the crop plants due to adverse physico-chemical properties. Gypsum is naturally occurring mineral which is a cheaper source of calcium and commonly used as inorganic amendment which exchange the sodium and thereby improve soil structure due to process of flocculation. The flocculated soils have better porosity as compared to dispersed soils.

\section{Introduction}

Salt-affected soils occur in several countries of the world, especially in the arid and semi-arid areas and also in coastal tracts. In India, more than 7.0 million hectares of land is affected by salinity and alkalinity (Anonymous, 2015). The common salts responsible for this menace are carbonates, bicarbonates, chlorides, sulphates and occasionally nitrates of sodium, calcium, magnesium and potassium which come from the weathering of rocks and minerals. The salts so generated are often carried away by water which is the chief transporting agent to varying distances, depressions, valleys etc. When water evaporates, salts are left behind to give rise to saline soils. Under conditions when calcium and magnesium salts go out of solution due to their limited solubilities, the proportion of sodium in soil solution increases. This results in considerable adsorption of sodium on the exchange complex giving rise to alkali soils. Application of chemical amendments with or without organic manure for reclamation decreased soil $\mathrm{pH}$, exchangeable $\mathrm{Na}$ and $\mathrm{Mg}$, and increased exchangeable $\mathrm{Ca}$ and soil salinity. Sorghum yield and nutrient uptake were increased with the application of amendments. Combining organic manure with chemical amendments had a favorable effect on soil chemical properties and plant growth which were more pronounced than their sole application Noufal (2006). 
The common salts responsible for this menace are carbonates, bicarbonates, chlorides, sulphates and occasionally nitrates of sodium, calcium, magnesium and potassium which come from the weathering of rocks and minerals. The salts so generated are often carried away by water which is the chief transporting agent to varying distances, depressions, valleys etc. When water evaporates, salts are left behind to give rise to saline soils. Under conditions when calcium and magnesium salts go out of solution due to their limited solubilities, the proportion of sodium in soil solution increases. This results in considerable adsorption of sodium on the exchange complex giving rise to alkali soils. Among the inorganic amendments, gypsum and pyrites are generally used in Uttar Pradesh. However, the gypsum is more efficient in reclamation of salt-affected soils, but it is costly. On the other hand pyrites is cheaper but it needs complete oxidation for its efficient use which is limited at higher $\mathrm{pH}$ in these soils. After reclamation of salt-affected soils, the tolerant crops like wheat, barley, berseem and mustard should be grown which improve the physical as well as chemical characteristics of soils. soil amendments significantly improved the growth and grain yield of wheat. Plant height, number of tillers plant-1, number of grains spike-1 and 1000 grains weight were significantly increased with all the soil treatments over control. The highest grain yield of $3989 \mathrm{~kg}$ ha-1 was obtained from combined application of deep tillage $+100 \%$ gypsum requirement of the soil showing $59.87 \%$ increased over control. Thus, it may be concluded that deep tillage and gypsum both in combination proved more effective in combating ill effects of salts and improving wheat yield in salt- affected soil Abdur Rashid et al., (2009).

Wheat (Triticum aestivum L.) is a staple food of world, belong to family poaceae. It is primarily grown in temperate regions and also higher altitudes and at medium altitudes in tropical climate areas in winter season. Recently, the consumption of wheat in the form of flour and bread has been increased significantly in the tropical regions. It is the single most important cereal crop that has been considered as integral component of the food security system of several regions. Uttar Pradesh ranks first in respect to area $(9.25 \mathrm{~m}$ ha) and production $(25.60 \mathrm{mt})$ but the productivity is much lower $\left(28.0 \mathrm{q} \mathrm{ha}^{-1}\right)$ than Punjab (43.9 q ha ${ }^{-1}$ ) (Anonymous, 2015). The productivity of wheat in eastern Uttar Pradesh might be due to adoption of cereal-cereal (Rice-wheat) cropping system, late sowing, cultivation in salt-affected soils and poor management. Due to effective reclamation of sodic soils, the productivity of wheat may be increased.

\section{Materials and Methods}

The experiment was conducted at the Main Experiment Station (MES) of Narendra Deva University of Agriculture and Technology, Narendra Nagar (Kumarganj), Faizabad (U.P.). The experimental site is situated about 42 kms, away from Faizabad city on FaizabadRaibarelly road. The soil of Main Experimental Station (MES), Kumarganj, is saline-sodic in nature exhibiting high $\mathrm{pH}$ values and exchangeable sodium percentage. Drainage is impeded due to low permeability of soil. Kankar pan at variable depth ranging from 0.5 to 1.5 meters are found. Gypsum requirement and other important characteristics of the soil of experimental field as determined from a composite soil sample drawn before starting the experiment.

The experimental operations were started with leveling of experimental field followed by preparatory irrigation. Later at optimum moisture content, the field was ploughed and leveling was done. The experiment was laid out in the well prepared field as per layout 
plan consisting of eleven treatments replicated three times. In all, there were 33 plots each measuring 20 meter sq. and partitioned by 50 $\mathrm{cm}$ bunds with adequate provision of irrigation and drainage channels. The gypsum was applied@ @75\% and @ 100\% GR value. It was broadcasted in the field and mixed well in shallow depth. Just after the application of gypsum, a heavy irrigation was applied. After 3-4days, the plot were drained and again flooded with fresh water. This process was continued up to 21 days. After that the organic materials were added as per materials.

The wheat crop was grown after month of application of organic materials. The plots were then made ready for sowing of crops. Just before sowing N,P,K and Zn were applied @ $120 \mathrm{~kg}, 60 \mathrm{~kg}, 40 \mathrm{~kg}$ and $25 \mathrm{~kg} / \mathrm{ha}$ of each by the urea, Single Super Phosphate (SSP), Murate Of Potash (MOP) and Zinc Sulphate $\left(\mathrm{ZnSO}_{4}\right)$ respectively. The half does of nitrogen and full does of $\mathrm{P}, \mathrm{K}$ and $\mathrm{ZnSo}_{4}$ were applied as basal dressing remaining half does of nitrogen was applied as top dressing into equal splits at different stage. Wheat variety Lok-1 was sown @ $150 \mathrm{~kg} / \mathrm{ha}$ on $28^{\text {th }}$ December, 2011 in $20 \mathrm{~cm}$ apart at the depth of $4-5 \mathrm{~cm}$ with the help of kudal. Three irrigations were given after sowing of wheat at various critical stages of the crop growth. Intraculture operations were done after the first and second irrigation to keep the soil in proper condition and free from weed.

The plant height $(\mathrm{cm})$ was wheat measured the help of meter scale at 30,60 DAS (Days after Sowing) and before six days of harvest of the crop. The length between the base of stem touching the ground and top most tip of the plant was considered as height of plant and averaged. The number of effective tillers per running meter was counted before the harvest of crop. In individual plots, five plants were selected randomly and number of grains in ear was counted and average value obtained as used. The total weight of grains harvested from net area was recorded. The yield per plot was converted into $\mathrm{q} / \mathrm{ha}$. The weight of straw calculated by subtracting the grain yield from the total biological yield of crop. Finally, straw yield per plot was converted into $\mathrm{q} / \mathrm{ha}$.

\section{Results and Discussion}

Most of the salt-affected soils of Uttar Pradesh are sodic or Saline-sodic in nature. Their reclamation invariably involves the addition of suitable amendments to replace the exchangeable sodium followed by leaching operations. The approaches for increasing crop production in these soils are feasible, changing the soil environment favorable for the growth of the plant or changing the plant genetically to better tolerate the environment. I have taken the approach with a view to improve the physico-chemical properties of sodic soil to suit better crop growth and yield, using gypsum as an amendment alone and its combination with Farm Yard Manure, Press mud, Paddy Straw and Sobabool leaf. One crop viz. wheat was also undertaken to see that how crop is better in improving physicochemical properties and reclamation of sodic soil.

The effectiveness of different soil amendments on growth and yield contributing characters of wheat crop such as number of tillers and number of effective tillers (per running meter), plant height $(\mathrm{cm})$ at 90 DAS, number of grains per spike, grain and straw yields of wheat crops.

Data presented in Table 1 that the maximum plant height at 60 DAS $(45.66 \mathrm{~cm})$ was observed in gypsum @ 100\% G.R. + press mud @ 10t/ha $\left(\mathrm{T}_{7}\right)$ treatment which was significantly superior over control. The minimum value $(27.16 \mathrm{~cm})$ was recorded in the control plots $\left(\mathrm{T}_{1}\right)$. The statistical analysis of data reveal that maximum number of 
effective tillers/ running meter (56.10) was obtained with $\mathrm{T}_{7}$ followed by $\mathrm{T}_{5}$ (54.56), $\mathrm{T}_{11}$ (52.15), $\mathrm{T}_{9}$ (49.13), $\mathrm{T}_{6}$ (48.18), $\mathrm{T}_{4}$ (46.56), $\mathrm{T}_{10}$ (45.89), $\mathrm{T}_{8}$ (44.14), $\mathrm{T}_{3}$ (43.13), $\mathrm{T}_{2}$ (42.96) and $\mathrm{T}_{1}$ (40.49) treatments respectively. Maximum number of grain /ear was found in gypsum @ 100\% G.R + press mud @ 10t/ha followed by gypsum @ 100 \% G.R.+ FYM @ 10t/ha treatments (39.00 and 37.00) respectively. Minimum number of grain /ear was recorded under control plot (21.00). Gypsum and its combination with organic materials have been resulted in significantly higher number of grain /ear over gypsum alone and control.

Maximum grain yield (18.89q/ha) was obtained with the application of gypsum @ $100 \%$ G.R.+ press mud @ 10t/ha which was at par with $\mathrm{T}_{5}$ (Gypsum @ 100\% G.R. + FYM @ 10t/ha) and significantly higher than rest of the treatments. There has been tremendous increase in grain yield with the application of gypsum alone and in combination with organic materials over control. Minimum grain yield $(4.07 \mathrm{q} / \mathrm{ha})$ was obtained in control plots. Further reveal that maximum straw yield (28.40q/ha) was obtained with @ 100\% G.R. gypsum application along with @ 10 t/ha press mud followed by @ 100\% G.R.gypsum + @ 10 t/ha FYM (27.34q/ha), @ 100\% G.R. gypsum +@10t/ha subabul leaf $(24.07 \mathrm{q} / \mathrm{ha})$, @ 100\%G.R. gypsum + @10t/ha paddy straw (23.87q/ha), @ $75 \%$ G.R.gypsum + @10t/ha press mud (20.91q/ha), @75\% G.R.gypsum +@10t/ha FYM (19.93q/ha), @ 75 \%G.R. gypsum +@10t/ha subabul leaf (18.74q/ha), @ 75\% G.R.gypsum + @ 10t/ha paddy straw $(16.00 \mathrm{q} / \mathrm{ha}), \quad @ 100 \% \quad$ G.R.gypsum (14.33q/ha), @ 75\% G.R.gypsum (12.00q/ha) and control (11.04q/ha) respectively.

Table.1 Effect of soil amendments on plant height, no. of effective tillers, no. of grains/ear, grain yield and straw yield of wheat in sodic soil

\begin{tabular}{|c|}
\hline Treatments \\
\hline Control \\
\hline Gypsum @ 75 \% GR value \\
\hline Gypsum @ 100 \% GR value \\
\hline $\begin{array}{l}\text { Gypsum @ } 75 \text { \% GR value + FYM } \\
\text { @ } 10 \text { t/ha }\end{array}$ \\
\hline $\begin{array}{l}\text { Gypsum @ } 100 \text { \% GR value + FYM } \\
\text { @ } 10 \text { t/ha }\end{array}$ \\
\hline $\begin{array}{l}\text { Gypsum @ } 75 \text { \% GR value + Press } \\
\text { mud @ } 10 \text { t/ha }\end{array}$ \\
\hline $\begin{array}{l}\text { Gypsum @ } 100 \text { \% GR value + Press } \\
\text { mud @ } 10 \text { t/ha }\end{array}$ \\
\hline $\begin{array}{l}\text { Gypsum @ } 75 \text { \% GR value + Paddy } \\
\text { straw @ } 10 \text { t/ha }\end{array}$ \\
\hline $\begin{array}{l}\text { Gypsum @ } 100 \text { \% GR value + } \\
\text { Paddy straw @ } 10 \text { t/ha } \\
\end{array}$ \\
\hline $\begin{array}{l}\text { Gypsum @ } 75 \text { \% GR value + } \\
\text { Subabool leaf @ } 10 \text { t/ha }\end{array}$ \\
\hline $\begin{array}{l}\text { Gypsum @100\% GR value + } \\
\text { Subabool leaf @ } 10 \text { t/ha }\end{array}$ \\
\hline SEm \pm \\
\hline CD at $5 \%$ \\
\hline
\end{tabular}

\begin{tabular}{|c|c|c|c|c|}
\hline $\begin{array}{c}\text { Plant height } \\
(\mathbf{c m}) \text { 60 DAS }\end{array}$ & $\begin{array}{l}\text { No. of effective } \\
\text { tillers } \mathbf{m}^{-1}\end{array}$ & $\begin{array}{l}\text { No. of } \\
\text { grains/ear }\end{array}$ & $\begin{array}{l}\text { Grain yield } \\
(\mathbf{q} / \mathbf{h a})\end{array}$ & $\begin{array}{l}\text { Straw yield } \\
(\mathbf{q} / \mathbf{h a})\end{array}$ \\
\hline 27.16 & 40.49 & 21.00 & 4.07 & 11.04 \\
\hline 31.33 & 42.96 & 25.00 & 6.57 & 12.00 \\
\hline 33.26 & 43.13 & 26.00 & 7.43 & 14.33 \\
\hline 37.45 & 46.56 & 32.00 & 10.34 & 27.34 \\
\hline 44.64 & 54.56 & 37.00 & 17.83 & 20.91 \\
\hline 38.66 & 48.18 & 33.00 & 11.89 & 28.40 \\
\hline 45.66 & 56.10 & 39.00 & 18.89 & 16.00 \\
\hline 34.71 & 44.14 & 28.00 & 8.00 & 27.87 \\
\hline 39.38 & 49.13 & 34.00 & 14.00 & 18.74 \\
\hline 35.11 & 45.89 & 29.00 & 9.01 & 24.07 \\
\hline 41.44 & 52.15 & 36.00 & 16.86 & 0.857 \\
\hline 1.645 & 1.951 & 1.3000 & 0.479 & 2.530 \\
\hline 4.853 & 5.757 & 3.834 & 1.141 & \\
\hline
\end{tabular}


It is interesting to note that all the treatments were tremendously effective over control. The observations revealed that gypsum proved the most effective amendment in combination of press mud or FYM in increasing the yield and related crop characters, such as maximum plant height at different stages, number of tillers and number of effective tillers per running meter, number grains spike ${ }^{-1}$, test weight $(\mathrm{g})$, grain and straw yield, respectively was maximum in gypsum $100 \%$ G.R. value + press mud @ $10 \mathrm{t}$ $\mathrm{ha}^{-1}$ treatment. The next effective treatments after gypsum + press mud, in increasing the yield and other related crop characters was gypsum in combination with FYM or subabool leaf.

A highly significant response of gypsum + press mud was observed on these parameters when gypsum and its combination treatments are compared with control. It becomes apparent that press mud further increase the efficiency of this amendment. The observation of the data showed that gypsum by virtue of its calcium, proved to be the most effective ameliorant in augmenting crop yield. The calcium content present in the gypsum directly reacts and replaces the sodium of clay complex; hence its efficiency to improvement was good. The same trend was given by Kanwar and Chawala (1969), Bhumbla and Abrol (1972) and Abrol et al., (1973).

The efficiency of gypsum must have further increased due to the decomposition of press mud, FYM and gradual release of nitrogen and mineral nutrients, helpful in development of plant and which eventually resulted in better yield and yield contributing characters. Gypsum in conjunction with press mud or FYM is helpful to provide condition for the development of the crop due to improved physico-chemical properties of the soil. The beneficial effect of gypsum in combination with press mud and FYM on crop yield have also been reported by Rudraksha et al., (1978); Daragan (1982), Tripathi and Singh (1983) and Patel et al., (1983).

\section{References}

Abdur Rashid Khan, R.U. and Marwat, S.K. (2009). Response of wheat to soil amendments with poor quality irrigation water in salt affected soil. World Journal of Agricultural Science, 5 (4): 422-424.

Abrol, I.P., Dargan, K.S. and Bhumbla, D.R. (1973). Reclaiming alkali soils. Bulletin No. 2, CSSRI, Karnal, p. 58.

Bhumbla, D.R. and Abrol, I.P. (1972). Effect of application of different levels of gypsum on the yield of rice, wheat and barley grown in saline-sodic soils. Intern. Symp. New Develop in the field of salt-affected soils. Dec. 4-9, pp. 537-44.

Dargan, K.S., Singh, O.P. and Gupta, I.C. (1982). Crop production in salt-affected soil, CSSRI, Karnal, pp. 7.

Kanwar, J.S. and Bhumbla, D.R. (1969). Physicochemical characteristics of sodic soils of the Punjab and Haryana and their amelioration by use of gypsum, Agrokem. Talait, 18 (Suppl.): 315-20.

Noufal, E.H.A. (2006). Studies on cultivation and reclamation of a sodic soil. Annals of Agricultural Science, Moshtohor, 44 (2): 775-797.

Rudraksha, G.B., Rbhaambe, P.R. and Varade, S.B. (1978). Reclamation of alkali soils with rice culture in association with different agricultural wastes. J. Maharastra Agril. Univ., 3: 160-161.

Tripathi, P.N. and Singh, R. (1983). Effect of soil amendments on nutrient uptake and yield of wheat in salt-affected soil. Paper presented at National Symposium on Plant Nutrition. Lucknow University, Lucknow, pp. 21.

\section{How to cite this article:}

Manish Rao, K.K. Verma, Gurmukh Gyani, Anoop Singh and Ashok Kumar. 2018. Effect of Soil Amendments on Growth and Yield of Wheat (Triticum aestivum L.) in Sodic Soil. Int.J.Curr.Microbiol.App.Sci. 7(09): 595-599. doi: https://doi.org/10.20546/ijcmas.2018.709.070 